\title{
Theoretical Approach of Science, Technology and Innovation for Economic Growth in Mozambique
}

\author{
Isaque Manteiga Joaquim \\ School of Economics, Shandong University, Jinan City, China
}

Email address:

imjoaquim20@yahoo.com

To cite this article:

Isaque Manteiga Joaquim. Theoretical Approach of Science, Technology and Innovation for Economic Growth in Mozambique. Science Journal of Business and Management. Vol. 5, No. 3, 2017, pp. 110-115. doi: 10.11648/j.sjbm.20170503.14

Received: March 21, 2017; Accepted: April 20, 2017; Published: May 4, 2017

\begin{abstract}
This paper presentation reflects literature review and the theoretical approaches on the relevance of the interdependent dynamics of Science, Technology and Innovation (STI) and their relationship to economic growth. The paper will do a review on literature of case studies and will aim to understand how the STI indicators have been applied or not applied in Mozambique for framing policy on economic planning purpose. Evolutionary theories like those of Schumpeter and others have complex and dynamic approaches which are conceptually attractive. In this paper we examine their respective virtues and limitations, and their visibility when connected with practical policy-making. In this context, the paper aims to examine the relative strengths and weaknesses of science and technology in the economy of Mozambique and analyze the policies identified to support the development of science, technology and innovation. This theoretical approach will also reflect on the relevance of the interdependent policy issues relating to the dynamics of science, technology and innovation and their relationship to economic growth.
\end{abstract}

Keywords: Science, Technology, Innovation, Theory, Economic Development, Growth

\section{Introduction}

Advances in the technology have been the main driving force of the industrialized countries, responsible for much of the increase in productivity. Since the beginning of the modern discipline, economists have written about economic development and identified technological progress as the main driving force [Schumpeter, 1911]. In the 1950s and 1960 s, many studies have tried to measure the contribution of technological change to economic growth in some countries where the production was in the frontiers of technology. It was concluded that technological advances were largely responsible for the increase in labor productivity. Since that time, there was a vast theoretical and empirical literature on technological progress in the advanced industrial countries.

In the context of Africa's development, it is important to keep in focus that science, technology and innovation could contribute not only to economic growth, but also to enhancing the quality of life of the poor. A broader understanding of innovation and technology is therefore needed. An understanding that encompasses both economic development based on the conceptualization and commercialization of new products and services, and also social development that improves the quality of life of impoverished communities. Furthermore, this understanding of innovation and technology should not only implore business entrepreneurs and technical specialists to be innovative, but also encourage impoverished communities to be innovative for their own benefit.

The context of STI is not the exclusive domain of rich countries, nor even of the rich in poor countries. Innovation and technology should be undertaken not only by those such as technological entrepreneurs but also by those who themselves are caught in the web of poverty. The challenge is to help foster an environment that channels the creativity of the community members to exploit opportunities for development. In short: Science, Innovation and Technology should be for the community, by the community.

Mozambique ranks poorly on the Knowledge Economy index ${ }^{1}$, thus it is not surprising that there is very little

1 The data used for KAM 2012 rankings are the most recent data available when the rankings were published, and not necessarily 2012 data. For the most recent 
information that is readily available concerning innovation in the country. This may be ascribed to relatively low activity levels of innovation in the country, as well as to the fact that very little information that relates to innovation is published, whether electronically or in print.

Mozambique is considered one of the countries with the best economic performance in sub-Saharan Africa. Over the past decade, Mozambique's average annual economic growth has been $8 \%$, mainly driven by megaprojects, industry, services and strong support by donors' countries. These megaprojects, financed by FDI inflows, had no significant impact on either employment creation or government revenues or economic diversification [African Development Bank Group et al. 2013²: 258]. On the contrary, actual economic model is characterized by high social inequalities and a high external dependency. Despite the good economic performance in recent years, Mozambique remains a country with many challenges, especially the reduction of poverty, a present unstable political situation, and a high dependency on primary products.

It is being increasingly recognized in Mozambique that STI has a key role to play in the development of the country. As evidence to that, a national science and technology policy was adopted in 2003, and in 2005 the science and technology function that resided in the then Ministry of Education, Science and Technology was established as the separate Ministry of Science and Technology (MCT). MCT is now playing the key role in stimulating the country to recognizes the importance of STI, and of coordinating the various actors within the innovation arena.

\section{Literature on Technology and Innovation}

The old orthodox theory quoted from Solow, $1956^{3}$ argued that countries that differ in terms of initial productivity levels but not in terms of other aspects (population growth and saving propensities) tend to converge towards the same level and the same rate of growth of productivity. This is the result of a theoretical perspective in which technology is considered as a public good, freely available to everyone, and its dynamics are largely unexplained. In this case all will catch-up in the productivity and income, considering that the market forces operate freely. The heterodox theory focuses on innovation activities in companies as the driving force behind economic growth for the successful innovative companies do benefit economically due to the temporary monopoly receiving from the innovations applied. The problems that

year used for each variable, see www.worldbank.org/kam.

2 The Africa Competitiveness Report 2013 (The Africa Competitiveness Report 2013 is the result of collaboration among the World Economic Forum, the World Bank, the African Development Bank, and the Ministry of Foreign Affairs of Denmark.)

3 A neo-Schumpeterian Approach to Why Growth Rates Differ, par Fulvio Castellacci, Pages 1145 - 1169. the theoretical and traditional empirical approaches of the neoclassical growth faced was to explain the "stylized facts" of long-term growth and the emergence of other competing approaches, led eventually to a survey of neoclassical theorists for new models growth that could be made according to what could actually be observed, without abandoning the neoclassical framework completely.

Table 1. The innovation literature done by 10 major contributors.

\begin{tabular}{|c|c|c|c|c|}
\hline 1 & $\begin{array}{l}\text { Nelson RR \& } \\
\text { Winter S }\end{array}$ & $\begin{array}{l}\text { An Evolutionary Theory of } \\
\text { Economic Change }\end{array}$ & USA & 1982 \\
\hline 2 & Nelson RR & National Innovation Systems & USA & 1993 \\
\hline 3 & Porter ME & $\begin{array}{l}\text { The Competitive Advantage of } \\
\text { Nations }\end{array}$ & USA & 1990 \\
\hline 4 & Schumpeter JA & $\begin{array}{l}\text { The Theory of Economic } \\
\text { Development }\end{array}$ & & $\begin{array}{l}1912 \\
(1934)\end{array}$ \\
\hline 5 & Rogers EM & $\begin{array}{l}\text { The Theory of Economic } \\
\text { Development }\end{array}$ & USA & 1962 \\
\hline 6 & Lundavall B- & $\begin{array}{l}\text { National Innovation Systems - } \\
\text { Towards a Theory of Innovation and } \\
\text { Interactive Learning }\end{array}$ & UK & 1992 \\
\hline 7 & Freeman $\mathrm{C}$ & $\begin{array}{l}\text { The Economics of Industrial } \\
\text { Innovation }\end{array}$ & USA & 1974 \\
\hline 8 & $\begin{array}{l}\text { Cohen W \& } \\
\text { Levinthal D }\end{array}$ & Absorptive Capacity & USA & 1990 \\
\hline 9 & Pavitt K & $\begin{array}{l}\text { Sectoral Patterns of Technical } \\
\text { Change }\end{array}$ & UK & 1984 \\
\hline 10 & Pavitt K & $\begin{array}{l}\text { Economic Welfare and Allocation of } \\
\text { Resources for invention }\end{array}$ & USA & 1962 \\
\hline
\end{tabular}

Source: Fagerberg, J., Fosaas, M. and Sappraset (2012).

\subsection{Innovation and Economic Growth}

Innovation is a widespread phenomenon that affects growth in all parts of the world. Fagerberg (1987) identified three factors that affect the differentiated growth rates between countries: innovation, imitation, and other efforts related to the commercial exploitation of technology as growth forces. The analysis suggests that innovative activity was the main factor behind the huge performance gap between Asian and Latin American countries in the 1970s and early 1980s. Fagerberg and Verspagen (2002) also found that the continued rapid growth of the Asian newly industrialized countries in relation to other groups of countries in the decade that followed was mainly caused by the rapid growth in the innovative performance of the region. The survey also indicated that while imitation has become more demanding over time (and therefore more difficult and/or expensive to accomplish), innovation has gradually become a more powerful factor in explaining the differences between the countries economic growth.

\subsection{Technology Transfer Mechanisms}

The technology transfer process generates development over time when it is able to adopt the economics of technological knowledge, and more advanced methods of organization and management, which take irreversible advances in other areas, productivity, innovation, scientific research etc. On the other hand, its impact goes beyond the GDP growth and reflects on the direct employment, indirect 
employment created by growth links, increase and income distribution, and quality of life of the society as a whole. The technology transfer process allows a link between consumers networks, suppliers, cooperation between firms networks, and create dynamic links growing between local and foreign firms or between local firms beyond the enhancement of existing dynamic links.

Technology transfer, as indicated by Kim quoting Cooke and Mayes, takes place via certain mechanisms that can be identified per area of technology as follows:

a) Technology in the form of knowledge can be conveyed through print media, oral discussions, television or radio.

b) Technology in the form of skills is acquired by doing something. These skills can be acquired from training, watching, observing or demonstrations

c) Technology in the form of equipment which is conveyed through products, trade conventions, conventions and advertisement.

The technology transferred as above can be divided in two major categories: Passive and Active. This classification refers to the level of activity in applying the technology in the transfer process. However, the boundaries between passive and active modes are not that easy to define. If the technology transfer mechanism presents the technology to the potential user without assistance regarding its application, then the mode is called passive. In the passive mode only the knowledge part of technology is transferred, the skills surrounding the technology are not transferred. If, on the other hand the provider of the technology assists with the application of the technology, such as the case in training, then the mode is called active.

\section{Science, Technology and Innovation in Mozambique}

\subsection{Institutions of Higher Education, Research, Science and Technology}

The higher education in Mozambique dates back to 1962 with the creation of the University Eduardo Mondlane (UEM). In 1985, another institution was established - the Higher Pedagogical Institute (ISP). The ISP was later transformed into Pedagogical University (UP) in 1995, thus setting up the second Public University in the country.

To date, the country currently has 49 higher education institutions from Public (18) and private (31), with about 200,000 students of which $41 \%$ are in the public system and $59 \%$ in the private system, supported by almost 8000 teachers of different categories from undergraduate degrees to doctors, of which 731 are doctors, 200 foreigners.

According to Vargas, the evolution of the higher education system is critical to the success of the model of importation, adaptation and generation of technology adopted because there is no technology transfer if no qualified people to absorb it, because the technology is not in machines, in books/ manuals, processes or patents. It is indeed the head of its human agents.

Figure 1 and Figure 2 show the enrollment by field of training in 2011, although are for only some years, these data are consistent with the data presented in previous annual reports to this. The Figures illustrate that the most preferred scientific area is the one of Social Sciences and Arts followed by Education and Natural Sciences, both in public and in private institutions. The majority of students are in undergraduate degree level and almost zero in the doctoral level, which indicates low human resource capacity for research in these institutions and the country in general.

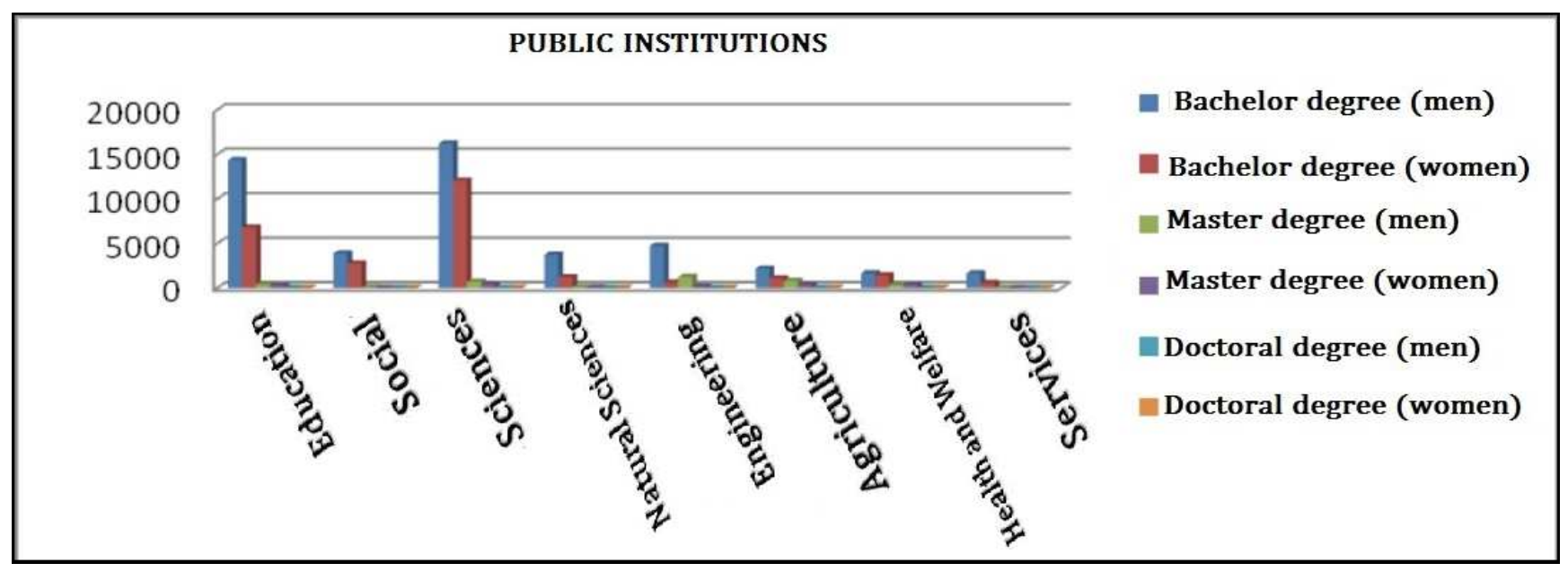

Source: Ministry of Education - Statistic data from 2011 updated in 2015

Figure 1. Students enrolled in Public Universities by course, Degree and gender.

The proliferation of higher education institutions in recent years coupled with the small number of teachers with doctoral degree will lead to increased demand for teachers with only undergraduate degree and the few existing teachers tend to teach in many institutions, weakening the quality of higher education in the country. 


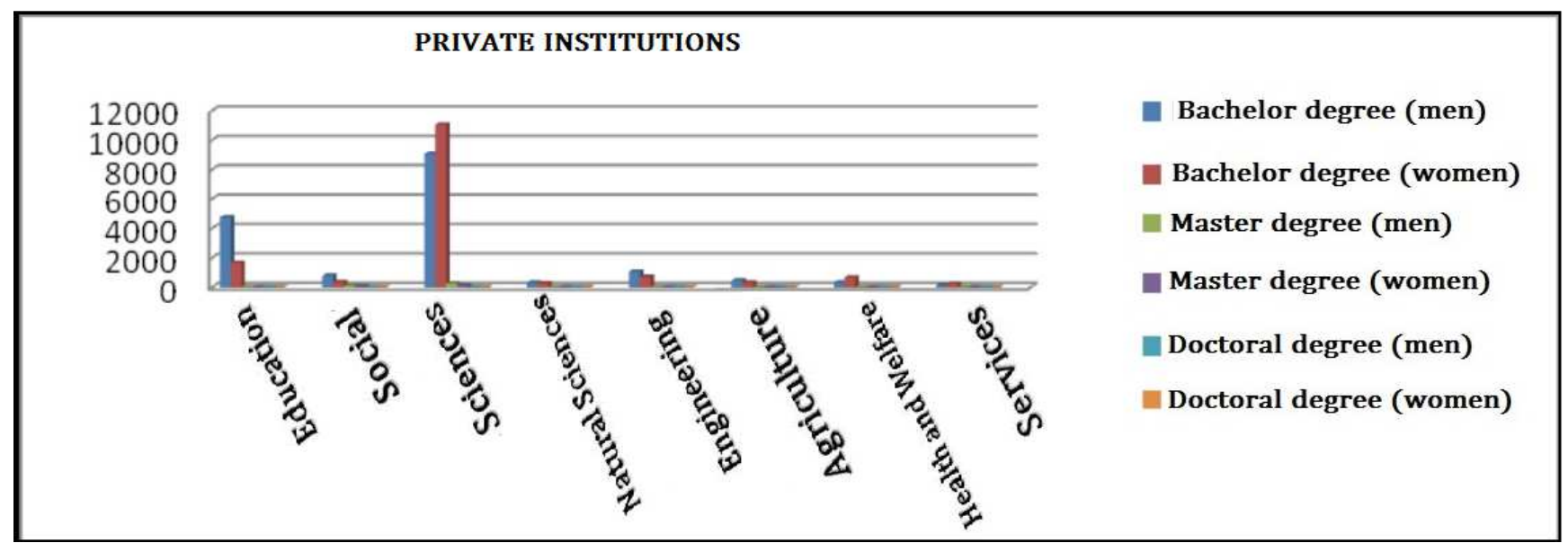

Source: Ministry of Education - Statistic data from 2011 updated in 2015

Figure 2. Students enrolled in Private Universities by Course, by Degree and gender.

\subsection{Institutes and Centers of Research and Innovation}

In parallel with the education system, the Ministry of Science and Technology (MCT) is the central body of the state apparatus responsible for the Formulation of policies and strategies for the development of Science and Technology as well normalization, standardization and coordination in development of Science and Technology as shown in Figure 3. MCT is mandated with promoting scientific research and technological innovation, technological research and innovation methodologies based on professional ethics and values that ensure benefits to the economic, social and cultural development;

The National Research Fund, overseen by MCT, funds mechanisms for Science and Technology around research and development infrastructure, innovation and technology transfer and the general development of science and technology.

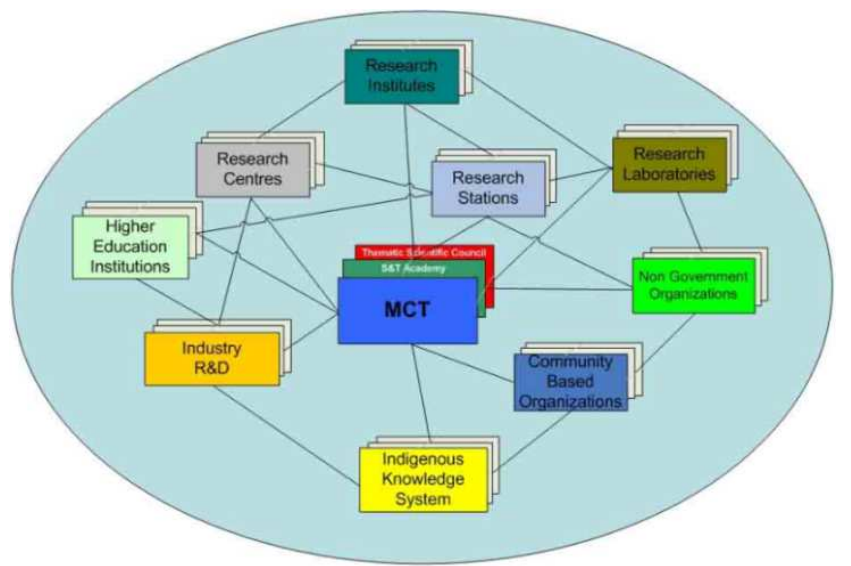

Figure 3. MCT the central body of Mozambique's National Science and Technology

4 Mozambique Science, Technology and Innovation Strategy (MOSTIS), 2006, pg 83.

\subsection{Production Structure of Mozambique}

The Mozambican economy is dominated by three sectors: Services; Agricultural sector and the Industrial sector as highlighted in Table 2. The Services sector includes trade, restaurants, hotels, transport and communications, finance and government services while the Agricultural sector employs about $83 \%$ of the population with $97 \%$ of production in this sector is of subsistence. The main industries of the country are aluminum, natural gas, prawns, cashews, cotton, sugar, lime, wood and raw power. The countries of destination for Mozambique's exports of are the Netherlands (aluminum), South Africa, Portugal and China and the main countries of origin of imports are South Africa, the Netherlands, India and Portugal [MINAG, 2010].

Mozambique's economy, with a characteristically extractive accumulation mode [Castelo-Branco \& Mandlate 2012], is dominated by large international capital associated with domestic capitalism outbreaks, usually farmer and dominantly speculative or service whose global strategy is characterized as " accumulation by dispossession "of natural resource revenues in poor countries.

Apart from aluminum and gas, sectors with significant growth in the industry are the food and drinks (because of tobacco exported sheet and beverage industry with a high level of concentration of ownership and control of production and trade nonmetallic regional) and non-metallic minerals (cement for construction). In other sectors of the economy also recorded the same trends as disarticulation, simplification and production for extraction.

From Table 2, it is observed that agriculture is the sector that absorbs the major labor force, and yet is the least growing as compared to industry and service sectors. This low growth and higher concentration of the work is explained by the fact that Mozambique's economy is mainly agrarian and agriculture is predominantly of subsistence, characterized by low levels of production and productivity, since more than $98 \%$ of agricultural exploitations practice rain-fed agriculture [MINAG, 2010-2014]. The industry 
sector and services together absorb only $21 \%$ of the workforce but nevertheless contribute about $55.3 \%$ of GDP. Within the industry sector, the subsector that has more contributed for industrial GDP is the extractive industry, with special focus on minerals and energetic resources. While the most prominent service sector goes to transportation, communication and trade.

\subsection{Alignment of the Productive Structure with Science, Innovation and Technology}

The relationship between educational sectors, research and production, according to literature review presented here, can be concluded that there is an alignment between the training areas, research institutes and research centers, whether private or public. However, these are disjointed to the productive structure from the point of view of the productive potential that the country has. In this study, there are few registrations in terms of preferences to the fields of natural sciences that could be applied in agriculture and industry sectors which contribute about $70 \%$ of GDP. This structure of the national system of science and innovation, is not comparable with that of countries experienced and advanced in science and technology and hence poses a need to align STI with productive structures.

The large companies which the country has, are mostly of a foreign intensive capital and are concentrated in the extractive sector. According to the Bank of Mozambique, only between $3 \%$ and $5 \%$ of foreign direct investment income is reinvested in Mozambique [Castelo-Branco \& Mandlate, 2012]. The studies show that multinationals conduct their research in the countries of origin but has in recent years, especially in the countries of Asia and the Pacific some foreign direct investment in Research and Development [UNCTAD, 2004]. But there is no statistical data based on each institution, or how many partnerships have already been implemented between STI institutions and firms neither any result produced in these partnerships, which somehow makes it difficult to evaluate the performance of these institutions in the economy.

Table 2. Production structure of Mozambique.

\begin{tabular}{llll}
\hline Sector & Growth Rate \% (2012) & Contribution to GDP, 2010 & Contribution of Human capital *2004/05) \\
\hline Agriculture & 6.8 & $44.8 \%$ & $79.00 \%$ \\
Industry & 10 & $23.40 \%$ & $3.00 \%$ \\
Services & 7.7 & $31.90 \%$ & $18.00 \%$ \\
Total of the country & 8 & $100.00 \%$ & $100.00 \%$ \\
\hline
\end{tabular}

Source: UNDP Mozambique, July 2012.

\section{Conclusion}

By focusing on the process of transformation brought by each set of dominant technologies in its specific historical and socio-institutional context, the paper was based on neo-Schumpeterian approach to explain why growth rates differ between countries. The main idea put forward is that the process of catching up, forging ahead and falling behind is the complex outcome of the adaptation of the country to the emerging technological paradigm. The paper ultimately sought to reinforce the fact that advances in technology has been the main driving force of the industrialized country, responsible for much of the increase in productivity.

Countries differ in their timing of entry into the new long wave (dependent on their "technological congruence") and in the speed at which the new paradigm diffuses and becomes dominant (dependent on their "social capability" and on their "facility for structural change"). We have noted that the developing countries obtain their technologies from the industrialized world and face problems on how to utilize, master, adapt and improve the knowledge of the equipment imported. Technological development occurs in a learning process, but obtaining a minimum level of operational skills (know-how) is essential for productive activity. Challenges can be faced, depending on the technology and the ability to understand its principles (know-why).

There are no clear articulation between education and research institutions and companies, (no statistical data based on each institution, how many partnerships have already been implemented or the results produced in these partnerships) which somehow makes it difficult to evaluate the performance of these institutions in the economic growth in Mozambique.

Mozambique's STI strategy recognizes the need for an integrated approach to innovation, with strong linkages to the key sectors of the economy, and for the need to harness innovation for poverty reduction as well as provision of a coherent framework for innovation-related initiatives. This holistic approach breaks with the existing patterns and mindsets of working within disjoint domains. It is essential that all stakeholders align themselves with the strategy and contribute to its implementation in an integrated and cooperative way. Furthermore, key priorities within the strategy should be identified and resources focused on these, so that the enormity of the task does not dilute available resources to the extent that they become ineffective.

\section{References}

[1] Castelo Branco, C. N. Oksana Mandlate, 2012. Da economia extractiva à diversificação da base produtiva: $\mathrm{O}$ que pode o parp utilizar da análise do modo de acumulação em moçambique?

(http://www.iese.ac.mz/lib/publication/livros/des2012/IESE_ Des2012_6.EconExt.pdf).

[2] FAGERBERG, J. "Technology, Policy, Growth - Theory, Evidence and Interpretation," Nordic Journal of Political Economy, Nordic Journal of Political Economy, vol. 25, pages 5-14. 1999. 
115 Isaque Manteiga Joaquim: Theoretical Approach of Science, Technology and Innovation for Economic Growth in Mozambique

[3] FAGERBERG, J. (2003) Schumpeter and the revival of evolutionary economics: an appraisal of the literature, Journal of Evolutionary Economics 13:125-159.

[4] FAGERBERG, J. "Innovation - a New Guide," Working Papers on Innovation Studies 20131119, Centre for Technology, Innovation and Culture, University of Oslo. 2013.

[5] KIM, L. e NELSON, R. R. A tecnologia e a industrialização em economias de industrialização recente. Campinas, SP: Editora da UNICAMP, 2005.

[6] MINISTÉRIO DA EDUCAÇÃO. Dados Estatísticos sobre o Ensino Superior em Moçambique 2011 -2015

(http://www.mctestp.gov.mz/?q=content/institui\% $\% \mathrm{C} 3 \% \mathrm{~A} 7 \% \mathrm{C}$ 3\%B5es-de-es).

[7] MINAG. Ministry of Agriculture and Rural Development (PEDSA 2010 - 2019) Maputo, 2010 source (http://fsg.afre.msu.edu/mozambique/caadp/PEDSA_FINAL_ 10Out.pdf).
[8] Nelson, R. R. \& Winter, S. G. Uma teoria evolucionária da mudança econômica. Campinas, SP: Editora da UNICAMP, 2005. (1 ${ }^{\mathrm{a}}$ reimpressão, 2012).

[9] Republic of Mozambique, Mozambique Science, Technology and Innovation Strategy (MOSTIS), 2006.

[10] SCHUMPETER, J. The Theory of Economic Development, Cambridge, Mass. 1911.

[11] SCHUMPETER, J. Business Cycles I-II. New York:McGraw-Hill 1939.

[12] UNCTAD (2004) The impact of FDI on development: Globalization of R\&D by transnational corporations and implications for developing countries, United Nations, dezembro 2004 (http://www.unctad.org/en/docs/com2em16d2_en.pdf $>$ ). 